\title{
1 International Journal of Epidemiology peer reviewers: global and gender
}

\section{2 distribution}

3

4 Gwinyai Masukume, MB ChB, MSc ${ }^{1, *}$, Julio González-Álvarez, PhD², Victor Grech, MD,

$5 \quad \mathrm{PhD}^{1}$

6

$7 \quad{ }^{1}$ Academic Department of Paediatrics, Medical School, Mater Dei Hospital, Malta

$8{ }^{2}$ Department of Basic and Clinical Psychology and Psychobiology, University Jaume I,

9 Castellón de la Plana, Spain

*Correspondence: parturitions@gmail.com 
medRxiv preprint doi: https://doi.org/10.1101/2020.05.14.20101964; this version posted May 19,2020 . The copyright holder for this preprint (which was not certified by peer review) is the author/funder, who has granted medRxiv a license to display the preprint in perpetuity.

It is made available under a CC-BY 4.0 International license .

\section{Abstract}

22 The science of epidemiology studies and analyses the patterns, distributions and determinants

23 of health-related entities. Peer review is crucial to the biomedical journal ecosystem.

24 Furthermore, gender inequality persists in science and improving gender representation is a

25 key international goal. For these reasons, we evaluated the geographical location and gender

26 distribution of the International Journal of Epidemiology peer reviewers for 2018.

27 There were 695 peer reviewers hailing from 41 countries. 77\% (533) of the reviewers were

28 from 20\% (8) of these countries, a classical 80:20 Pareto distrubution.

$2941 \%$ (282) of peer reviewers were female. Although in line with the general

30 underrepresentation of females reported in the literature, this proportion was much closer to

31 parity than in other fields.

32 Our investigation of peer reviewer 'epidemiology' demonstrates geographical and gender

33 inequalities that can be further improved since diversity promotes innovation and a greater

34 possibility for solving complex problems.

$36 \quad$ Key words

37 Epidemiology, peer-review, gender, equity 
medRxiv preprint doi: https://doi.org/10.1101/2020.05.14.20101964; this version posted May 19, 2020. The copyright holder for this preprint (which was not certified by peer review) is the author/funder, who has granted medRxiv a license to display the preprint in perpetuity.

It is made available under a CC-BY 4.0 International license.

42 The science of epidemiology studies and analyses the patterns, distributions and determinants of health-related entities. ${ }^{[1]}$ The International Journal of Epidemiology (IJE) content is a

44 valuable resource that keeps readers abreast of the latest advances in this field. ${ }^{[2]}$ Peer reviewers are vital to the biomedical journal ecosystem. ${ }^{[3]}$ We studied and analysed the 'epidemiology' of IJE peer reviewers using 2018 data (Figure 1). ${ }^{[4]}$

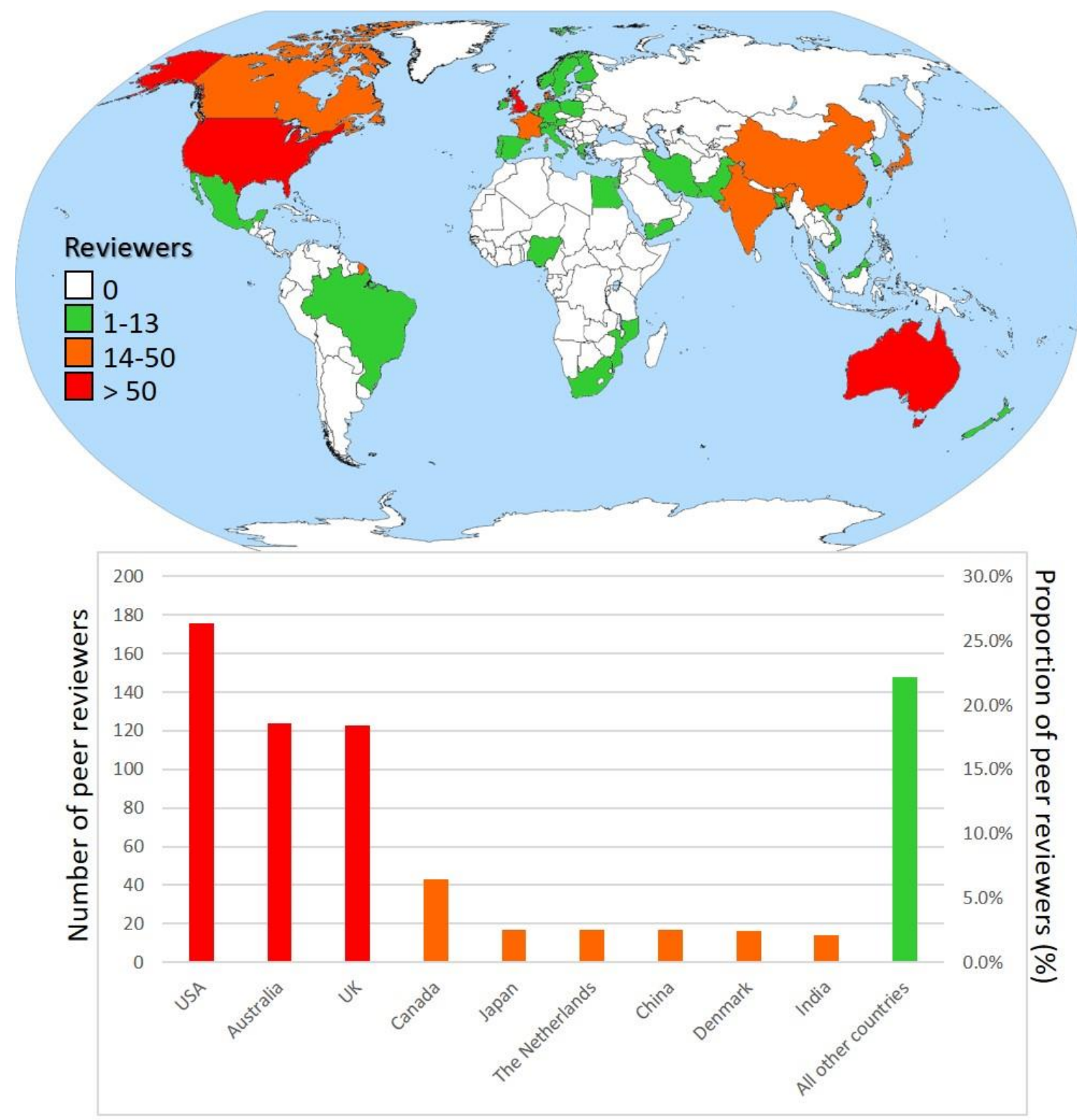

\section{Country}


medRxiv preprint doi: https://doi.org/10.1101/2020.05.14.20101964; this version posted May 19, 2020. The copyright holder for this preprint (which was not certified by peer review) is the author/funder, who has granted medRxiv a license to display the preprint in perpetuity.

It is made available under a CC-BY 4.0 International license .

Figure 1. Number and location of The International Journal of Epidemiology peer reviewers, 2018.

There were 695 peer reviewers from all six permanentely inhabitated continents, hailing from

41 countries. $77 \%$ (533) of the reviewers were from $20 \%$ (8) of these countries. This pattern adheres to the $80 / 20$ Pareto principle ( $80 \%$ of events emanate from $20 \%$ of attributary causes). Ranking was: South America 1\% (8), Africa 2\% (13), Asia 10\% (69), Oceania 19\% (130), North America 32\% (222) and Europe 36\% (253).

A previous analysis of $I J E$ authors revealed that among first authors, $44 \%$ of them were from the United States of America (USA) and United Kingdom (UK). Our findings mirror these with $43 \%$ (299) of the reviewers from the USA and UK. Rounding out the top three referee countries was Australia with $18 \%$ (124). This top three country distribution was similar to that of The Lancet's, another leading medical journal. ${ }^{[5]}$

The greater proportion of referees from high-income countries is determined by availability of more research funding, better access to reliable census and mortality data, more possibilty of protected time to do research and greater facility with the English language. ${ }^{[4]}$

65 Because gender inequality exists in science, we also considered peer reviewer gender. ${ }^{[6]} \mathrm{We}$ used https://gender-api.com/, the largest online resource that determines gender based on first name. This was supplemented by ascertaining gender from internet searches for reviewer biographical and photographic information. We found that $41 \%$ (282) of peer reviewers were female. Although in line with the general underrepresentation of females reported in the

70 literature, this proportion was much closer to parity than in other fields. ${ }^{[6]}$ Promoting gender equity is a key aspect of the international Sustainable Development Goals. ${ }^{[7]}$ 
medRxiv preprint doi: https://doi.org/10.1101/2020.05.14.20101964; this version posted May 19, 2020. The copyright holder for this preprint (which was not certified by peer review) is the author/funder, who has granted medRxiv a license to display the preprint in perpetuity.

It is made available under a CC-BY 4.0 International license .

72 It is worth noting that one reviewer could have performed multiple reviews and our analysis

73 did not take this into account. In addition, reviewer numbers were absolute counts and not

74 relative to a country's population.

75 Our concise investigation of IJE peer reviewer 'epidemiology' allows a baseline from which geographical and gender representation can be further improved. Greater diversity promotes innovation and a higher possibility for solving complex problems. ${ }^{[8]}$

\section{Ethics}

80 Research ethics committee approval was not required because of the public nature of the

81 dataset.

\section{Conflict of interest}

$84 \quad$ None declared.

\section{$86 \quad$ Funding}

87 No specific funding was received.

\section{References}

90 1. Anderson W. The history in epidemiology. International journal of epidemiology.

$91 \quad 2018 ; 48(3): 672-4$.

92 2. Grant C, Williams B, Driscoll T. Historical trends in publications in the International

93 Journal of Epidemiology. International journal of epidemiology. 2018;47(3):938-41. 
medRxiv preprint doi: https://doi.org/10.1101/2020.05.14.20101964; this version posted May 19,2020 . The copyright holder for this preprint (which was not certified by peer review) is the author/funder, who has granted medRxiv a license to display the preprint in perpetuity.

It is made available under a CC-BY 4.0 International license .

$943 . \quad$ Glonti K, Boutron I, Moher D, Hren D. Journal editors' perspectives on the roles and

95 tasks of peer reviewers in biomedical journals: a qualitative study. BMJ Open.

$96 \quad 2019 ; 9(11): \mathrm{e} 033421$.

974 Leeder S. The IJE and the volatile world of academic publication. International 98 journal of epidemiology. 2019;48(2):323-31.

99 5. Masukume G, Grech V. The Lancet peer reviewers: global pattern and distribution. 100 Lancet (London, England). 2018;391(10140):2603-4.

101 6. González-Alvarez J, Cervera-Crespo T. Psychiatry research and gender diversity:

102 authors, editors, and peer reviewers. Lancet Psychiatry. 2019;6(3):200-1.

103 7. Gupta GR, Oomman N, Grown C, Conn K, Hawkes S, Shawar YR, et al. Gender

104 equality and gender norms: framing the opportunities for health. Lancet (London, England).

105 2019;393(10190):2550-62.

106 8. Phillips KW. How Diversity Works. Scientific American. 2014;311(4):42-7. 